\title{
Can This Marriage Be Saved? Personality Assessment and Clinical Psychology in the $21^{\text {st }}$ Century
}

\author{
Bruce L. Smith \\ University of California, Berkeley
}

\begin{abstract}
This article examines the role of psychological assessment in modern clinical psychology. Based upon survey research, it is argued that there has been a decline in the importance of assessment in practice despite the recent increase in opportunities. Forensic psychology, outcome evaluation, and therapeutic assessment were identified as areas of opportunity. This decline has been attributed to changes in psychiatric practice, declining reimbursement for services, office expenses for assessment psychologists, and declining education and training in graduate schools. These trends are alarming because of the threat that they pose to the continued practice of psychological assessment. The importance of assessment for the identity of psychologists as well as for optimum treatment is stressed and several recommendations are made for increasing the visibility of assessment within psychology and for research designed to demonstrate its value. Trends in the United States are briefly compared with those in other countries, including Serbia.
\end{abstract}

Keywords: psychological assessment, clinical psychology, forensic psychology, outcome evaluation, therapeutic assessment

For some time, psychologists in the United States have been concerned with the declining importance of assessment in clinical practice. Assessment is the defining characteristic of clinical psychology in that it is the one area of practice that is unique to psychology. Psychiatrists, social workers, counsellors, even clergy conduct psychotherapy, but only psychologists are trained to conduct assessments. According to surveys taken over the years, the percentage of practice time devoted to psychology has declined from $44 \%$ in 1944 to $10-15 \%$ in surveys done in 2005 and 2009 (Wright, Beattie, Galper, Church, Bufka, Brabender, and Smith, 2016). 
This decline has had several causes. During the 1940's and earlier, psychologists in the U.S. were generally not permitted to practice psychotherapy independently. This began to change in the 1960's as the need for psychotherapeutic services increased. By the 1970's, when psychologists were first licensed in most states, psychotherapy had become the centrepiece of most psychologists' practices. Practice opportunities further expanded in the following decades; many states granted psychologists permission to admit and treat patients independently in hospitals in the 1980's, and by the start of the $21^{\text {st }}$ century, several states even permitted psychologists to prescribe psychotropic medication.

A second cause has had to do with changes in mental health practices in the United States. Increasingly, the first line of treatment for most disorders is medication. In addition, hospital stays have been steadily decreasing. When I was working in psychiatric inpatient facilities in the 1970's, average lengths of stay were measured in months. Today, most patients in the U.S. are discharged from inpatient care in a week or less. As a consequence, less attention is paid to careful diagnosis and nuanced treatment planning. Choosing the "right" medication is largely a process of trial and error. In addition, at least in the U.S., psychiatrists and even non-psychiatric physicians have discovered that by replacing thoughtful psychological assessment with short symptom questionnaires (typically administered by office staff), they can add a "service" for which they can bill. Although such "assessments" are minimal at best, if the only goal is symptom-reduction through medication, they may appear to be sufficient.

Finally, the rise of cognitive behavioural therapy (CBT) as the dominant mode of psychotherapy has lessened the interest in the assessment of the whole person. CBT therapists especially those who practice predominantly "manualized" treatment ${ }^{14}$ are less interested in the patient's personality configuration and more interested in the observable symptoms.

Finally, these factors are paralleled by a decline in assessment training in graduate programs. In the United States, clinical psychology practice requires a doctorate degree, and psychologists receive most if not all of their training in graduate school. In years past, students typically received around two years of didactic instruction in psychological testing and assessment, including courses on the theory of tests and measurement, diagnostic interviewing, cognitive assessment, objective personality assessment (i.e., the use of personality inventories), and projective assessment (the use of tests such as the Rorschach, the Thematic Apperception Test, Figure Drawings, etc.). Today, some programs have as little as a single semester devoted to assessment.

14 Manualized treatment refers to the practice of following a strict written protocol for conducting therapy. 


\section{Current Assessment Practice}

There is a paradox here. Although the training in and practice of assessment has been declining, in more recent years, the opportunities for the expansion of assessment practice have actually been growing. In order to further explore the state of assessment within psychology in the U.S., my colleagues and I conducted a survey of American psychologists 2009 (Wright, Beattie, Galper, Church, Bufka, Brabender, and Smith, 2016). Our interest was in determining what they were doing in terms of assessment, how much assessment they were doing, and what were the barriers to increasing their assessment practice. We sent out 1973 surveys and received 301 back (return rate of $16.7 \%$ ). We found that the majority of them $(61 \%)$ were working in outpatient settings (private practice, outpatient clinic, etc.), and $80 \%$ did at least some assessment regularly. Among those who did practice assessment, they averaged about 6 hours/week administering tests, and about 6.6 hours/week scoring, interpreting, and writing up test findings. Those who practiced either in inpatient settings or in forensic work averaged twice as much time doing assessment than those who were doing outpatient clinical work.

The following table shows the main reasons for conducting assessments. A single assessment may have multiple reasons.

Table 1

\begin{tabular}{|ll|}
\hline Diagnosis & $85 \%$ \\
Recommendations for treatment & $79 \%$ \\
Screening for cognitive deficit & $71 \%$ \\
Treatment planning before therapy & $62 \%$ \\
Psychoeducational assessment (e.g., learning disabilities) & $52 \%$ \\
Addressing an impasse in treatment & $47 \%$ \\
Forensic questions & $46 \%$ \\
Therapeutic Assessment & $40 \%$ \\
Monitoring/measuring treatment progress & $39 \%$ \\
\hline
\end{tabular}

In terms of the assessment instruments used, the list turns out to be fairly similar to those from previous surveys. Psychologists appear to be using the same group of tests as they have been in the past. Of course, many of these instruments have been updated. For instance, the Wechsler Adult Intelligence Scale (WAIS) is now on its $4^{\text {th }}$ edition, with a fifth to be released later this year. Similarly, the Minnesota Multiphasic Personality Inventory (MMPI) was updated to the MMPI-2 in the 1980's and to the MMPI-2-RF (Revised Format) about 10 years ago. Table 2 shows the most commonly used instruments from our survey. 
Table 2

\begin{tabular}{|lc|}
\hline Symptom Specific tests (e.g., Beck Depression Inventory) & $78 \%$ \\
MMPI & $78 \%$ \\
WAIS & $76 \%$ \\
Mini Mental Status Examination (MMSE) & $67 \%$ \\
Wechsler Intelligence Scale for Children (WISC) & $59 \%$ \\
Woodcock-Johnson Achievement Scales & $56 \%$ \\
Millon Clinical Multiaxial Inventory (MCMI) & $54 \%$ \\
Rorschach & $54 \%$ \\
Projective Tests (TAT, Figure Drawings, Sentence Completion, etc.) & $49 \%$ \\
Child Behavior Check List (CBCL) & $49 \%$ \\
Halstead-Reitan Neuropsychological Battery & $45 \%$ \\
Personality Assessment Inventory (PAI) & $38 \%$ \\
\hline
\end{tabular}

When the psychologists were asked about what were the barriers to increasing their assessment practices, $68 \%$ cited reimbursement as the main problem. As health care costs have been rising in the U.S., insurers (including the government) have been looking at ways to cut costs, and psychological practice has been a prime target. As a consequence, the reimbursement for assessment services has been cut and even more importantly, psychologists are being asked to use fewer tests and conduct their assessments in fewer hours. The second leading problem cited was the cost of testing materials. A new WAIS now costs well over $\$ 1000$, scoring software for tests such as the PAI may be $\$ 500$ or more, and even something as simple as a deck of 10 Rorschach cards is nearly $\$ 200$. In order to have a successful private assessment practice, a psychologist probably has to invest at least $\$ 5000$ in testing materials, many of which will need to be updated periodically. The third problem area was the lack of ongoing education and training. With new research and new instruments, it is necessary for psychologists to have ongoing continuing education in order to remain up to date in their assessment practice. Until recently, there were not enough opportunities for such education, although this appears to be changing.

While the barriers listed above are cited by current practitioners, the greatest long term threat to assessment practice is the reduction in training in assessment in graduate schools. This, in turn, leads to a decline in interest in psychological assessment among younger colleagues. This is extremely ironic because it is occurring at a time when there are newer opportunities for assessment practice emerging. Many psychologists just entering practice are discovering that there are now opportunities for conducting assessments that they aren't fully trained for. 


\section{Expanding Opportunities for Assessment Practice}

One area of growth is that of forensic assessment. Increasingly, the courts in the United States are turning to psychologists for expert opinions on a wide range of cases. In the past, the legal system tended to privilege psychiatrists as experts because of their medical degrees. More recently, however, psychologists have become the preferred experts because our use of psychological tests reduces some of the subjectivity and bias from expert opinions. Psychologists are now called upon to opine in criminal cases, cases of personal injury, sexual harassment, racial or gender discrimination, child custody and parental rights, and immigration. In all of these instances, psychological assessment is the cornerstone of the expert's opinion.

A second area that is increasing in importance is that of monitoring treatment progress. As practice in the U.S. is increasingly turning toward evidence-based practice, objective monitoring of the progress-or lack of progress-in treatment becomes an important aspect. Related to this is the need for psychological assessment services in general medical practice. In order to reduce health care costs, it is important to diagnose psychological problems that may be masquerading as physical, complicating medical conditions, or leading to a lack of compliance with medical treatment protocols. A number of assessment researchers are working on measures designed to address such issues.

Finally and perhaps most excitingly is the development of therapeutic assessment. Unheard of 20 years ago, therapeutic assessment may be the fastest growing area of assessment practice. Finn and his colleagues (Finn, 2007; Finn \&Tonsager, 1997) have developed a model that melds psychological assessment with brief psychotherapy such that the assessment both answers the clinical diagnostic questions and provides a powerful therapeutic experience for client. Research has demonstrated that therapeutic assessment is effective as a brief intervention for a wide variety of client problems (Poston \& Hansen, 2010). In addition, even when used primarily for diagnostic purposes, therapeutic assessment has been found to increase client satisfaction, compliance with recommendations and subsequent therapeutic alliance (Poston \& Hansen, 2010). More recently, Smith and Evans (2017) have developed a model that applies therapeutic assessment principles to the practice of forensic assessment. Their contention is that doing so improves the accuracy of the assessment and avoids re-traumatizing clients. The therapeutic assessment model is gaining in popularity in large measure because of the need to rein in health care costs. By providing a costeffective short-term treatment option or an assessment option that promises to shorten subsequent treatment, it is particularly attractive to those entities responsible for the payment for health care services. 


\section{Prospects for the Future}

As mentioned above, there is a paradox in that interest in assessment and assessment training in the academy is declining precisely at a time when research is demonstrating the utility of assessment as well as the effectiveness of newer instruments (e.g., MMPI-2-RF; Ben Porath, 2016) and the established ones (e.g., Rorschach; Meyer, Viglione, \&Mihura, 2017; Evans, 2017). In order for the former trend to be reversed, assessment psychologists need to make the value of assessment betterwellknown, both in the professional community and with the general public. One step in that direction has been the designation of a proficiency in assessment by the American Psychological Association. This means that assessment is officially recognized as a core area of expertise within professional psychology. The proficiency in assessment, administered by the Society for Personality Assessment, allows practitioners of assessment to have their work formally evaluated so that they may be declared as proficient in assessment.

One of the areas that need to be addressed is the lack of research that demonstrates the utility of psychological assessment. There is ample evidence for the reliability and validity of our major psychological instruments. We can be confident that we can accurately predict psychiatric diagnoses as well as certain behavioural patterns. What needs to be shown empirically, however, is that the kinds of predictions that can be made by assessment contribute either to more successful treatment, briefer treatment, or cost effectiveness. While there have been some studies that demonstrate the effectiveness of assessment (e.g., Poston \& Hanson, 2010; cited above), much more research in this area needs to be conducted so that we can argue for assessment services from a position of strength.

Internationally, the picture is mixed. In some countries, assessment is an integral part of clinical psychological practice. Patients in hospitals routinely receive a comprehensive assessment in Slovenia, for instance. In addition, I know from personal experience that over 200 psychologists in that country have received formal training in the Rorschach. Similarly, assessment is an important service in countries as diverse as Italy, Japan, and Argentina. On the other hand, there are nations in which assessment has been on the decline for a number of years, notably Canada, Germany, and the United Kingdom. I am not fully aware of the current state of affairs in Serbia, although I understand from colleagues that many of the same challenges exist. In addition, the lack of licensure for psychologists means that the practice of psychological assessment is not protected in the same way that it is in other countries (i.e., other professionals may use inventories, etc. with impunity).

In summation, it is my contention that psychological assessment remains a vital part of clinical psychology despite the evidence for its decline in 
importance in both the academy and the healthcare marketplace. The existence of expanding opportunities for assessment practice make it crucial that adequate training be available to psychologists entering the profession and continuing educational opportunities be available to those who are already established in practice. In so doing, we not only help the profession of clinical psychology, but the public we serve as well.

\section{References}

Ben-Porath, Y. S. (2012). Interpreting the MMPI-2-RF. Minneapolis, MN: University of Minnesota Press.

Evans, F. B. (2017). Using the CS in an R-PAS world: Multimethod forensic assessment with the Comprehensive System. In R. E. Erard\& F. B. Evans (eds.),The Rorschach in Multimethod Forensic Assessment. (pp. 316-332). New York: Routledge.

Finn, S. E. (2007). In Our Clients' Shoes: Theory and Technique of Therapeutic Assessment. New York: Routledge.

Finn, S. E. \&Tonsager, M. E. (1997). Information-gathering and therapeutic modes of assessment: Complementary paradigms. Psychological Assessment, 9, 374-385.

Meyer, G. J., Viglione, D. J., \&Mihura, J. L. (2017). Psychometric foundations of the Rorschach Performance Assessment System (R-PAS). In R. E. Erard\& F. B. Evans (eds.) The Rorschach in Multimethod Forensic Assessment. (pp. 23-91) New York: Routledge.

Poston, J. M. \& Hanson, W. E. (2010). Meta-analysis of psychological assessment as a therapeutic intervention. Psychological Assessment, 22, 203-212.

Smith, B. L. \& Evans, F. B. (2017). Collaborative/therapeutic assessment in multimethod forensic assessments. In R. E. Erard\& F. B. Evans (eds.) The Rorschach in Multimethod Forensic Assessment. (pp. 297-313) New York: Routledge.

Wright, C. V., Beattie, S. G., Galper, D. I., Church, A. S., Bufka, L. F., Brabender, V. M., and Smith, B. L. (2016). Assessment practices of professional psychologists: Results of a national survey. Professional Psychology: Research and Practice, 28, 73-78. 


\section{Može li se ovaj brak spasiti? Procena ličnosti i klinička psihologija}

\section{Brus L. Smit}

Univerzitet Kalifornije, Berkli

U radu se analizira uloga psihološke procene u savremenoj kliničkoj psihologiji. Anketa sprovedena među kliničkim psiholozima u Americi potvrđuje da je u praksi došlo do smanjenja značaja psihološke procene uprkos otvaranju novih mogućnosti njene primene. Forenzička psihologija, procena ishoda tretmana i terapijska procena su identifikovane kao područja koja otvaraju nove mogućnosti. Trend opadanja značaja psihološke procene je povezan sa promenama u psihijatrijskoj praksi, smanjenjem nadoknada za ove usluge, značajnim troškovima psihologa koji se bave procenom i redukovanjem akademskih programa i specijalizovanih treninga za edukaciju kliničkih psihologa. Ovi trendovi su upozoravajući zbog pretnje koju predstavljaju za kontinuiranu praksu psihološke procene. Istaknuta je važnost procene za identitet psihologa, kao i za optimalan tretman. Daje se i nekoliko preporuka za povećanje vidljivosti procene unutar psihologije i za istraživanja koja imaju za cilj da pokažu njenu vrednost. Trendovi u Sjedinjenim Državama su ukratko upoređen i sa onima u drugim zemljama, uključujući i Srbiju.

Ključne reči: psihološka procena, klinička psihologija, forenzička psihologija, evaluacija ishoda, terapijska procena 